\title{
Rendam Kaki Rebusan Air Jahe Merah Berpengaruh terhadap Penurunan Tekanan Darah Penderita Hipertensi
}

\author{
Fakhrudin Nasrul Sani ${ }^{1}$, Noor Fitriyani ${ }^{2}$ \\ ${ }^{1}$ UniversitasKusuma Husada Surakarta, email: fakhrudin.n.s1611@gmail.com \\ 2 Universitas Kusuma Husada Surakarta, email: pipitnizam87@gmail.com
}

\begin{abstract}
Abstrak. Hipertensi merupakan kondisi dimana tekanan darah seseorang melebihi batas normal yang ditetapkan, dimana kondisi tersebut dapat menimbulkan komplikasi berupa penyakit pada organ-organ tubuh lainnya. Pengobatan hipertensi terdiri dari pengobatan farmakologi dan nonfarmakologi. Salah satu pengobatan non farmakologi adalah hidroterapi yaitu rendam kaki air hangat. Penggunaan zat kompelementer dalam hidroterapi misalnya rendam kaki rebusan air jahe merah. Tujuan penelitian untuk mengetahui pengaruh rendam kaki rebusan air jahe merah terhadap penurunan tekanan darah penderita hipertensi di Posyandu Ngudi Rahayu RT 01/ RW 14, Bolon, Colomadu Karanganyar. Penelitian ini merupakan quasi eksperiman dengan rancangan One Group Pretest - Posttest Design. Populasi penelitian adalah lansia yang memiliki penyakit hipertensi primer di Posyandu Ngudi Rahayu RT 01/ RW 14, Bolon, Colomadu Karanganyar. Sampel penelitian sebanyak 42 responden yang ditentukan dengan teknik Purposive Sampling. Analisa data menggunanakan uji Wilxocon karena setelah dilakukan normalitas data hasilnya tidak normal. Hasil penelitian didapatkan rata-rata tekanan darah responden sebelum dan sesudah diberikan rendam kaki rebusan air jahe merah tekanan darah sistolik 149,05 mmHg menjadi $135,83 \mathrm{mmHg}$ dan diastolik 78,69 $\mathrm{mmHg}$ menjadi $75,95 \mathrm{mmHg}$. Hasil analisa uji korelasi menunjukkan ada pengaruh pemberian rendam kaki rebusan air jahe merah terhadap tekanan darah penderita hipertensi, ditunjukkan dengan nilai $p$-value $=0.0001$ (p-value $<0,05)$.
\end{abstract}

Kata kunci: Hipertensi, Tekanan darah, Rendam kaki rebusan air jahe merah

\section{Soak the foot with red ginger water, it has an effect on reducing blood pressure in hypertensive patients}

Abstract. Hypertension is a condition in which a person's blood pressure exceeds the established normal limits, where this condition can cause complications in the form of diseases in other organs of the body. Hypertension treatment consists of pharmacological and non-pharmacological treatments. One of the non-pharmacological treatments is hydrotherapy, which is soaking your feet in warm water. The use of complementary substances in hydrotherapy, for example, soak the foot of red ginger water. The research objective was to determine the effect of foot soaking with red ginger water on blood pressure reduction in hypertensive patients at Posyandu Ngudi Rahayu RT 01 / RW 14, Bolon, Colomadu Karanganyar. This research is a quasi experiment with One Group Pretest - Posttest Design. The study population was the elderly who had primary hypertension at Posyandu Ngudi Rahayu RT 01 / RW 14, Bolon, Colomadu Karanganyar. The research sample consisted of 42 respondents who were determined by purposive sampling technique. Data analysis used the Wilxocon test because after the normality of the data the results were not normal. The results showed that the average blood pressure of the respondents before and after being given the foot soak of boiled red ginger water, the systolic blood pressure of $149.05 \mathrm{mmHg}$ became $135.83 \mathrm{mmHg}$ and the diastolic $78.69 \mathrm{mmHg}$ became $75.95 \mathrm{mmHg}$. The results of the correlation test analysis showed that there was an effect of giving foot soaking in red ginger water on the blood pressure of hypertensive patients, indicated by the p-value $=0.0001$ (p-value $<0.05)$.

Keyword : Hypertension, Blood pressure, Soak the foot of red ginger water 


\section{Pendahuluan}

Hipertensi atau tekanan darah tinggi yaitu dimana kondisi tekanan sistolik lebih dari $140 \mathrm{mmHg}$ dan tekanan darah distolik lebih dari 90 mmHg. Hipertensi merupakan penyakit multifaktorial karena interaksi berbagai faktor. Peningkatan usia menyebabkan beberapa perubahan fisiologis, pada usia lanjut terjadi peningkatan resistensi perifer dan aktivitas simpatik (Setiawan, dkk, 2014).

Data World

Health

Organization (WHO) tahun 2015 menunjukkan sekitar 1,13 Miliar orang di dunia menyandang hipertensi. Jumlah penderita hipertensi terus meningkat setiap tahunnya, diperkirakan pada tahun 2025 akan ada 1,5 Miliar orang terkena hipertensi, dan diperkirakan setiap tahun 10,44 juta orang meninggal akibat hipertensi dan komplikasinya. Jumlah penderita hipertensi terus meningkat dari tahun ke tahun seiring dengan jumlah penduduk di Indonesia pada tahun 2013 sebanyak $25.8 \%$ dan pada tahun 2018 meningkat sebesar $34.1 \%$ atau 63.309 .620 orang, sedangkan angka kematian di Indonesia akibat hipertensi sebesar 427.218 kematian (Riskedas, 2013: Riskedas 2018). Penderita hipertensi di Propinsi Jawa Tengah juga mengalami peningkatan, pada tahun 2013 sebesar $25.8 \%$ dan pada tahun 2018 meningkat sebesar 57.10\% (Profil Kesehatan Jateng, 2018). Angka kejadian hipertensi di Kota Surakarta pada tahun 2017 sebanyak 54.691 kasus dan pada tahun 2018 meningkat menjadi 67.827 kasus (Profil Kesehatan Kota Surakarta, 2018).

Semakin bertambahnya usia seseorang, semakin besar kemungkinan seseorang mengalami permasalahan fisik, jiwa, spiritual, ekonomi dan sosial. Salah satu permasalahan pada lanjut usia adalah masalah kesehatan akibat proses degeneratif, hal ini ditunjukkan oleh data pola penyakit pada lanjut usia (Sambeka dkk, 2018). Penurunan pada kondisi fisik, psikologis maupun sosial merupakan proses menua yang dialami lansia dan proses ini berpotensi menimbulkan masalah kesehatan (Kristanto \& Maliya, 2012).

Salah satu terapi intervensi komplementer yang dapat dilakukan secara mandiri dan bersifat alami yaitu dengan hidroterapi kaki (rendam kaki air hangat). Pemberian rendaman kaki pada larutan hangat memberikan sirkulasi, mengurangi edema, meningkatkan sirkulasi otot. Rendam hangat akan menimbulkan respon sistemik terjadi melalui mekanisme vasodilatasi (pelebaran pembuluh darah). Merendam kaki air hangat akan memberikan respon lokal terhadap panas melalui stimulasi ini akan mengirimkan impuls dari perifer ke hipotalamus (Potter \& Perry, 2017).

Rendam kaki dapat dikombinasikan dengan bahan herbal salah satunya jahe. Jenis jahe yang dikenal oleh masyarakat yaitu jahe emprit (jahe kuning), jahe gajah (jahe badak), dan jahe merah (jahe sunti) tetapi jahe yang banyak digunakan untuk obat-obatan adalah jahe merah, karena jahe merah memiliki kandungan minyak atsiri yang lebih tinggi dibanding dengan jahe lainnya (Setyaningrum \& Sapiranto, 2013).

Rendam kaki dengan rebusan jahe merah dapat memberikan efek yaitu meningkatkan sirkulasi darah dan meningkatkan relaksasi otot tubuh. Jahe merah memiliki manfaat yang paling signifikan jika dibanding dengan jahe jenis jahe yang lain. Senyawa gingerol telah dibuktikan mempunyai aktivitas hipotensif. Kandungan gingerol berasal dari minyak tidak menguap (non volatile oily). Kandungan inilah yang membuat sensasi rasa hangat pada kulit saat 
tekanan darah paling tinggi 160/ 90 $\mathrm{mmHg}$

3. Distribusi tekanan darah pada lansia sesudah pemberian terapi rendam kaki jahe merah

Tabel 3.Distribusi tekanan darah pada lansia sesudah pemberian terapi rendam kaki jahe merah

\begin{tabular}{lcc}
\hline \multirow{2}{*}{ Nilai } & \multicolumn{2}{c}{ Tekanan darah } \\
\cline { 2 - 3 } & Systole & Diastole \\
\hline Min & 120 & 70 \\
Max & 150 & 90 \\
Mean & 135.83 & 75.95 \\
Standar Deviasi & 6.239 & 5.208 \\
\hline \multicolumn{1}{c}{ Berdasarkan } & tabel & tersebut
\end{tabular}

diperoleh rata - rata tekanan darah responden sesudah pemberian terapi rendam kaki jahe merah adalah 135.83 / $75.95 \mathrm{mmHg}$, tekanan darah paling rendah $120 / 70 \mathrm{mmHg}$ dan tekanan darah paling tinggi $150 / 90$ $\mathrm{mmHg}$

4. Analisis pengaruh rendam rebusan jahe merah terhadap mean arterial pressure

Tabel 4 Analisis Pengaruh rendam rebusan jahe merah terhadap mean arterial pressure

\begin{tabular}{lcr}
\hline & $\begin{array}{c}\text { Pre - Post } \\
\text { Test } \\
\text { Systole }\end{array}$ & $\begin{array}{c}\text { Pre-Post } \\
\text { Test } \\
\text { Dyastole }\end{array}$ \\
\hline $\mathrm{Z}$ & -5.497 & -2.370 \\
P value & 0,000 & 0.018 \\
\hline
\end{tabular}

Berdasarkan hasil analisis uji statistik wilcoxon menunjukkan bahwa ada pengaruh pemberian terapi rendam kaki jahe merah terhadap tekanan darah sebelum dan sesudah terapi rendam kaki jahe merah dengan nilai $p=0,000$ (Tek. Systole) dan $p=0,018$ (Tek. Dyastole) maka $\mathrm{p}<0,05$ sehingga ada pengaruh rendam kaki rebusan air jahe merah terhadap tekanan darah penderita hipertensi di Posyandu Ngudi Rahayu
RT 01/ RW 14, Bolon, Colomadu Karanganyar.

\section{Pembahasan}

1. Karakteristik responden

a. Jenis kelamin

Karakteristik responden berdasarkan jenis kelamin, menunjukkan sebagian besar responden berjenis kelamin perempuan yaitu $52.5 \% \quad(21$ responden). Menurut Singalingging (2011), rata-rata perempuan akan mengalami peningkatan risiko hipertensi atau tekanan darah tinggi setelah menopouse yaitu usia diatas 45 tahun.

Harison, et all (2012), mengatakan bahwa wanita yang belum mengalami menopause dilindungi hormon estrogen yang berperan dalam meningkatkan kadar high density lipoprotein (HDL). Kadar kolesterol HDL yang tinggi merupakan faktor dalam mencegah terjadinya proses aterosklerosis. Efek perlindungan estrogen dianggap sebagai penjelasan adanya imunitas wanita pada usia premenopause. Premenopause wanita, mulai kehilangan sedikit demi sedikit hormon estrogen yang selama ini melindungi pembuluh darah dari kerusakan.

Hasil penelitian ini sesuai dengan hasil penelitian Widhayani (2019), menyebutkan bahwa penderita hipertensi sebagian besar adalah perempuan dari 30 responden, 26 responden $(86,7 \%)$ berjenis kelamin perempuan.

b. Usia

Karakteristik responden berdasarkan usia, menunjukkan sebagian besar responden berusia 60 - 74 tahun yaitu 21 responden 
(52.5\%). Semakin tinggi usia seseorang cenderung semakin tinggi tekanan darahnya, orang yang lebih tua cenderung mempunyai tekanan darah yang tinggi dari orang yang berusia lebih muda (Harison,et all 2012). Kondisi yang berkaitan dengan usia ini adalah produk samping dari keausan arteriosklerosis dari arteri-arteri utama, terutama aorta, dan akibat dari berkurangnya kelenturan. Mengerasnya arteri-arteri ini, menjadikan arteri semakin kaku, arteri dan aorta kehilangan daya penyesuaian diri. Bertambahnya usia seseorang, risiko terkena hipertensi lebih besar sehingga pravelensi dikalangan lanjut usia cukup tinggi yaitu sekitar $40 \%$ dengan kematian sekitar $50 \%$ diatas usia 60 tahun. Arteri kehilangan elastisitas atau kelenturan serta tekanan darah meningkat seiring dengan bertambahnya usia (Brunner \& Suddarth, 2013).

Hasil penelitian ini sesuai dengan hasil penelitian Hanggraini (2018) dan hasil penelitian Widhayani (2019), menyebutkan bahwa sebagian besar responden berusia antara 60-74 tahun dan usia rata-rata berusia 63.87 pada pasien hipertensi. Hal ini sejalan dengan teori yang mengatakan meningkatnya tekanan darah seseorang seiring dengan bertambahnya usia seseorang, pada lansia tekanan darah pada lansia sistoliknya meningkat sehubungan dengan penurunan elastisitas pembuluh darah (Potter \& Perry, 2014)

2. Tekanan darah sebelum pemberian terapi rendam kaki jahe merah

Berdasarkan hasil penelitian diperoleh rata - rata tekanan darah responden sebelum pemberian terapi rendam kaki jahe merah adalah 149.05/78.69 $\mathrm{mmHg}$, tekanan darah paling rendah 135/70 $\mathrm{mmHg}$ dan tekanan darah paling tinggi 160/ 90 mmHg. Beberapa perubahan sistem tubuh akibat proses menua diantaranya meliputi ateroskrerosis, hilangnya elastisitas jaringan ikat, dan penurunan dalam relaksasi otot pembuluh darah, sehingga menurunkan kemampuan distensi dan daya renggang pembuluh darah (Smeltzer \& bare, 2014).

Penyebab hipertensi pada orang lanjut usia, disebabkan oleh terjadinya perubahan pada elastisitas dinding aorta menurun, katup jantung menebal dan menjadi kaku, kemampuan jantung memompa darah menurun, kehilangan elastisitas pembuluh darah. Hal ini terjadi karena kurangnya efektifitas pembuluh darah perifer untuk oksigenasi dan meningkatkan resistensi pembuluh darah perifer (Aspiri, 2014).

Penelitian ini sejalan dengan penelitian yang dilakukan oleh Nurahmandani, (2017). penelitian diketahui bahwa 17 responden penderita hipertensi diketahui bahwa lanjut usia yang berusia 60-74 tahun berjumlah 12 orang atau sebesar $70.6 \%$, sedangkan lanjut usia tua yang berusia 75-90 tahun berjumlah 5 $(72,3 \%)$. Kejadian hipertensi cenderung meningkat seiring dengan bertambahnya usia karena mengalami penurunan elestisitas, pelebaran dan kaku. Sebanyak 65\% orang Amerika 60 tahun atau lebih mengalami hipertensi (Prastyaningrum, 2014). Pada lansia perubahan struktur dan fungsional pada sistem pembuluh darah perifer bertanggung jawab pada perubaha tekanan darah. Perubahan tersebut meliputi aterosklerosis 
hilangnya elastisitas jaringan ikat, dan penurunan dalam dalam relaksasi otot polos pembuluh darah, yang pada gilirannya menurunkan kemampuan distensi dan daya regang pembuluh darah (Smeltzer \& Bare, 2013). Menurut peneliti makin bertambahnya usia dapat menyebabkan darah tinggi (Hipertensi). karena akan mengalami penurunan elastisitas dan akan mengalami penebalan pembuluh darah atau Aterosklerosis yang mengakibatkan penumpukan zat kolagen pada lapisan otot, sehingga pembuluh darah akan berangsurangsur menyempit dan menjadi kaku.

3. Tekanan darah sesudah pemberian terapi rendam kaki jahe merah

Berdasarkan hasil penelitian rata - rata tekanan darah responden sesudah pemberian terapi rendam kaki jahe merah adalah 135.83 / 75.95 mmHg, tekanan darah paling rendah 120/70 $\mathrm{mmHg}$ dan tekanan darah paling tinggi 150/ $90 \mathrm{mmHg}$. Hasil penelitian ini sejalan dengan penelitian Nurahmandani, Hartati \& Supriyono (2016) yang menunjukkan tekanan darah sesudah diberikan rendam kaki air jahe hangat pada lansia dengan hipertensi di Panti Werdha Pucang Gading Semarang dengan nilai mean MAP 103,29 mmHg. Rata-rata tekanan darah sistolik dan distolik sebesar 140.12/84.88 $\mathrm{mmHg}$, dengan standar deviasi $5.476 / 3.199 \mathrm{mmHg}$, nilai tengah 140.00/85.00 $\mathrm{mmHg}$ tekanan darah sistolik terendah 133/81 $\mathrm{mmHg}$ dan tekanan darah sistolik tertinggi 153/91 mmHg. Hasil penelitian Nurrahmandani (2016) tentang efektivitas pemberian terapi rendam kaki air jahe hangat terhadap penurunan tekanan darah pada lansia dengan hipertensi dipanti werdha Pucang Gading Semarang didapatkan hasil bahwa semua responden dengan jumlah 17 orang mengalami penurunan tekanan darah setelah perlakuan.

Air adalah media terapi yang tepat untuk pemulihan cidera, karena secara ilmiah air hangat dapat berdampak fisiologi tubuh. Pertama, berdampak pada pembuluh darah yaitu membuat sirlukasi menjadi lancar. Kedua, faktor pembebanan di dalam air akan menguatkan otot-otot ligament yang mempengaruhi sendisendi tubuh. Selain itu, suhu air yang hangat akan meningkatkan kelenturan jaringan disamping itu banyak yang dipengaruhi dengan jahe (Setyoadi \& Kushariyadi, 2011). Efektifitas terapi rendam kaki dengan air jahe hangat terhadap penurunan tekanan darah di karenakan merendam kaki dengan air jahe hangat dapat merileksasikan otot dan anggota gerak dam memperlebar pembuluh darah dari kaki dia alirkan ke pembuluh darah jantung dan merendam kaki dengan air jahe hangat dapat dengan suhu air $39^{\circ} \mathrm{C}$ dapat mengatasi kurang tidur, menghilangkan racun dan infeksi serta melancarkan pembuluh darah (Sucipto \& Setiyono, 2019).

4. Pengaruh terapi rendam kaki jahe merah terhadap tekanan darah pada penderita hipertensi di Posyandu Ngudi Rahayu RT 01/ RW 14, Bolon, Colomadu Karanganyar

Hasil analisa wilcoxon, didapatkan nilai $\mathrm{p}$ adalah 0,000 dan 0,018 dimana $\mathrm{p}<0,05$, sehingga $\mathrm{H}_{0}$ ditolak atau Ha diterima yang berarti bahwa ada pengaruh tekanan darah sistolik dan diastolik sebelum dan sesudah diberikan terapi rendam kaki jahe merah terhadap tekanan darah pada penderita hipertensi di Posyandu Ngudi Rahayu RT 01/ RW 14, Bolon, Colomadu Karanganyar. 
Hasil penelitian ini didukung oleh penelitian Nurahmandani, Hartati \& Supriyono (2016) yang menunjukkan bahwa terjadi penurunan tekanan darah sistolik dan diastolic sebelum maupun setelah diberikan rendam kaki air jahe hangat. Hasil analisis bivariat dengan menggunakan uji dependen t-test didapatkan hasil bahwa tekanan darah setelah dilakukan rendam kaki air jahe hangat terjadi penurunan tekanan darah sistolik dan distolik yaitu sebesar 17 orang lansia. Hasil Analisa bivariat dengan menggunakan Uji dependen ttest didapatkan $p$ value sistolik $=0.0001$ dan $p$ value diastolik $=0.0001$ maka Ha diterima dan Ho ditolak itu artinya terdapat evektifitas terapi rendam kaki air jahe hangat terhadap penurunan tekanan darah pada lansia dengan hipertensi di Panti Werdha Pucang Gading Semarang.

Merendam kaki dengan air hangat, air yang digunakan untuk terapi memiliki suhu $37-39^{\circ} \mathrm{C}$. Suhu tersebut dapat mengobati gejala kurang tidur dan infeksi, meningkatkan kelenturan otot jaringan ikat, kelenturan pada otot, mestabilkan kerja jantung dan alian darah, memberikan pengaruh pada sistem pembuluh darah sehinggan aliran darah menjadi lancer (Setiyoadi \& Kushariyadi, 2011). Merendam kaki dapat dikombinasi dengan rempahrempah salah satunnya yaitu jahe. Jenis-jenis jahe itu sendiri ada 3 yaitu jahe gajah, jahe kuning, dan Jahe merah, dikenal juga dengan sebutan jahe sunti, ukuran rimpangnya paling kecil di antara jahe lainnya. Warnanya merah, berserat kasar, dan rasanya sangat pedas. Kandungan minyak atsirinya 2,58-2,72\% (Lalage, 2015).
Jahe merah memiliki banyak keunggulan dibandingkan dengan jahe lainnya, terutama jika ditinjau dari segi kandungannya senyawa kimia dalam rimpangnya, sehingga jahe merah lebih banyak digunakan sebagai bahan baku obat. Jahe merah memiliki aroma yang tajam dan rasanya sangat pedas. Kandungan minyak atsiri pada jahe merah lebih tinggi dibanding dengan jahe lainnya (Setyaningrum \& Saparinto, 2013).

Manfaat jahe merah memberikan rasa pedas dan hangat jahe berasal dari senyawa gingerol (oleoresin). Rasa hangat jahe dapat merangsang pelepasan hormon adrenalin dan memperlebar pembuluh darah sehingga mempercepat dan memperlancar aliran darah serta meringankan kerja jantung, membantu pencernaan, mencegah gumpalan darah karena kandungan gingerol yang dapat menurunkan kadar kolestrol dengan cara mencegah sumbatan pembuluh darah yang menjadi penyebab utama stroke, mengatasi mual muntah, mencegah kerusakan sel (Kurniawati, 2010).

\section{Daftar Pustaka}

Anon. (2018). Manfaat Super Jahe Merah untuk Kesehatan. https://www.republikaonline. (diakses tanggal 24 Maret 2020).

Arinda, Nimas \& Khayati, Nikmatul.(2019). Rendam Kaki Dengan Rebusan Jahe Merah Dapat Mencegah Terjadinya Eklamsia. Jurnal Ilmu Keperawatan Maternitas, Vol 2 No 2

Aspiri. (2014). Keperawatan lanjut usia. Yogyakarta: Graha Ilmu.

Boeston dkk. (2010). Pedoman Diagnosa dan Terapi. Surabaya: RSUD Dr Soetomo. 
Dalimartha, S, Purnama, B,T, Sutarinaa, Nora, Mahendra, B, Dermawan, Rahmat. (2010). Care you self Hypertnsion. Jakarta: Penebar Plus.

Dewi, R. S. (2014). Keperawatan Gerontik. Yogyakarta: Deepublish.

Dinkes Jateng. (2018). Profil Kesehatan Provinsi Jawa Tengah Tahun 2018. Semarang: Dinkes Jateng.

Dinkes Kota Surakarta. (2018). Profil Kesehatan Kota Surakarta Tahun 2018. Surakarta: Dinkes Kota Surakarta.

Hafida, N. (2019). Bukan Jahe Biasa, ini 10 Khasiat Jahe Merah yang lebih Nendang Manjurnya. https://www.hipwee.com.

(diakses tanggal 23 Maret 2020).

Harmono dan Andoko. (2005). Budidaya dan Peluang Bisnis Jahe. Jakarta: Agromedia Pustaka.

Ilkafah. (2016). Perbedaan Penurunan Tekanan Darah Lansia dengan Obat Anti Hipertensi dan Terapi Rendam Air Hangat di Wilayah Kerja Puskesmas Antara Tamalanrea, Makassar. Pharmacon, Jurnal Ilmiah Farmasi, Unsrat, Vol. 5 No. 2.

Ira, H.S. (2014). Menu Ampuh Atasi Hipertensi. Yogyakarta : Notebook.

Jaya, M. (2009). Pembunuh Berbahaya Itu Bernama Rokok ( ( $1^{\text {st }}$ ed). Yogyakarta : Riz'ma.

Kemenkes RI. (2019). Hari Hipertensi Dunia 2019 : “Know Your Number, Kendalikan Tekanan Darahmu dengan Cerdik. Diakses $24 \quad$ Maret 2020. http://p2ptm.kemkes.go.id/kegiat an-p2ptm/pusat-/hari-hipertensidunia-2019-know-your-numberkendalikan-tekanan-darahmudengan-cerdik.
Kowalski, R.E. (2010). Terapi hipertensi: Program delapan minggu mengurangi tekanan darah dan mengurangi risiko serangan jantung dan stroke secara alami. Bandung: Mizan Pustaka.

Kristanto \& Maliya. (2012). Proses menua pada lansia dan implikasi kliniknya dalam buku ajar ilmu penyakit dalam, Edisi 4. Jakarta: Internal Publishing.

Kurniawati, N. (2010). Sehat dan Cantik Alami Berka Khasiat Bumbu Dapur. Bandung: Qanita

Lalage, Z. (2015). Hidup Sehat Dengan Terapi Air Cetakan Pertama. Klaten: Abata Press

Liana (2018), Efektifitas Terapi Rendam Kaki Dengan Air Jahe Hangat Terhadap Nyeri Arthritis Gout Pada Lansia. Proceeding Seminar Keperawatan Universitas Sriwijaya.

Martuti, A. (2009). Hipertensi Merawat dan Menyembuhkan Penyakit Tekanan Darah Tinggi. Bantul : Penerbit Kreasi Kencana.

Notoatmodjo, Soekidjo. (2018). Metodelogi penelitian Kesehatan. Jakarta: Rineka Cipta.

Nuraini, D. N. (2014). Aneka Manfaat Bunga untuk Kesehatan. Yogyakarta: Gava Media.

Nurahmandani.2016. Efektivitas pemberian terapi rendam kaki air jahe hangat terhadap penurunan Tekanan darah pada lansia dengan hipertensi di panti werdha pucang gadingsemarang.

http://ejournal.stikestelogorejo.ac.i d/index.php/ilmukeperawatan /article/view/500

Nurahmandani, A.R., Hartati, E., Supriyono, M. (2016). Efektivitas Pemberian Terapi rendam kaki Air Jahe Hangat terhadap Penurunan Tekanan darah pada 
Lamsia dengan Hipertensi dip anti Werdha Pucang Gading Semarang. Paimin F B., Murhananto. (2008). Seri Agribisnis Budi Daya Pengolahan, Perdagangan Jahe. Cetakan XVII. Jakarta: Penebar Swadaya.

Palmar, Anna. (2013). Simple guide tekanan darah tinggi. Jakarta: Erlangga.

Potter, P.A \& Perry, A.G. (2017). Buku Ajar Fundemental Keperawatan:Konsep, Proses, \& Praktik. Edisi 6 Volume 2. Jakarta: EGC.

Prihandhani, Sherlyna. (2016). Pengaruh Pemberian Kompres Hangat Rebusan Parutan Jahe Terhadap Nyeri Pada Lansia dengan Osterartritis di Pejeng Kangin, Kabupaten Gianyar. Jurnal Dunia Kesehatan, Volume 5.

Purwanto, B. (2013). Herbal dan Keperawatan Komplementer. Yogyakarta: Nuha Medika.

Rahayu, F. (2010). Formulasi Sediaan Chewable Lozenges yang Mengandung Ekstrak Jahe Merah (Zingiber officinale Rosc.Var.Rubrum). (Skripsi). Universitas Muhammadiyah Surakarta.

Riset Kesehatan Dasar. (2013). Jakarta: Badan Penelitian dan Pengembagan Kesehatan Kementrian Kesehatan RI.

Riset Kesehatan Dasar. (2018). Jakarta: Badan Penelitian dan Pengembagan Kesehatan Kementrian Kesehatan RI.

Riyanto, Budiman. (2014). Kapita Selekta Kuesioner Pengetahuan dan Sikap dalam Penelitian Kesehatan. Jakarta : Salemba Medika.
Santoso, H.B. (2008). Ragam \& Khasiat Tanaman Obat. Yogyakarta: PT Agromedia Pustaka.

Santoso, Dwi Agung. (2015). Pengaruh Terapi Rendam Kaki Air Hangat terhadap Penurunan Tekanan Darah pada Lansia Hipertensi di Wolayah Kerja UPK Puskesmas Khatuliswa, Kota Pontianak. Skripsi, Unversitas Tanjungpura, Pontianak.

Sambeka, Rahelea, Angela F.C \& Afnal A. (2018). Hubungan Kualitas Tidur dengan Hipertensi pada Lansia di Desa Tambun Kecamatan Likupang Barat Tahun 2018. Jurnal Kesehatan Masyarakat.

Setiawan, IWA, Yunani dan Kusyati. (2014). Hubungan Frekuensi Senam Lansia Terhadap Tekanan Darah Dan Nadi Pada Lansia Hipertensi. Prosiding Konferensi Nasional II PPNI Jawa Tengah, Semarang

Setyaning, R.D., Dewi, P., \& Suandika, M. (2014). Studi Pravelensi \& Kajian Faktor Risiko Hipertensi Pada Lansia di Desa Tambaksari, Banyumas. Jurnal Unimus. http://download.portalgaruda.org larticle.php (25 MAret 2020).

Setyaningrum, H.D., \& Saparinto, C. (2013). Jahe. Jakarta: Penebar swadaya

Setyoadi \& Kushariyadi. (2011). Terapi modalitas keperawatan pada klien psikogeriatrik. Jakarta : salemba

Smeltzer \& Bere. (2014). Keperawatan Medikal Bedah Brnner and Sudart edisi 10. Jakarta: EGC.

Soenarta, Arieska Ann. (2015). Pedoman Tatalaksana Hipertensi pada Penyakit Kardiovaskuler. Jakarta. PERKI (Perhimpunan Dokter Kardiovaskuler Indonesia).

Stanley \& Bere, (2010). Buku Ajar Keperawatan Gerontik. Jakarta: EGC. 
Sucipto, Muhamad Bayu \& Setiyono, Erwan.(2019). Efektifitas terapi rendam kaki dengan air jahe hangat terhadap penurunan tekanan darah pada pasien hipertensi di Puskesmas Kecamatan Cempaka Putih Jakarta Pusat.

Swari, R.C. (2017). Manfaat Jahe Merah untuk Kesehatan dari Pencernaan hingga Kesuburan. Helosehat.com. (Diakses tanggal 23 Maret 2020).
Tantochris. (2014). Kapita Selekta Kedokteran (2thed). Jakarta : EGC.

Tim Lentera. (2002). Khasiat \& Manfaat Jahe Merah Si Rimpang Ajaib. Jakarta: Agromedia Pustaka.

Utami, P. \& Puspaningtyas, D, E. (2013). Themiracle herbs. Jakarta: PT Agro Media Pustaka.

WHO. (2015). World Health Statistic Report 2015. Geneva : World Health Organization. 